\title{
THE FLEXIBLE MECHANISMS TO COMBAT CLIMATE CHANGE: A CRITICAL VIEW OF THEIR LEGITIMACY
}

\author{
ROSA M. FERNANDEZ EGEA* \\ Assistant Professor \\ Universidad Autónoma de Madrid \\ rosamaria.fernandez@uam.es
}

Received: November 11th 2010 / Accepted: December 13th 2010

\begin{abstract}
The Kyoto Protocol makes available the use of three economic mechanisms as a supplementary way of mitigating climate change: joint implementation, clean development mechanism and emission trading. They share the same rationale, which is to provide flexibility to achieve the compliance of the emission targets, allowing for the reduction of emissions at a minimum cost by efficiently allocating the responsibilities between agents. The new business opportunities they offer have attracted the attention of most developed and emerging countries. However, it is doubtful that they can bring an adequate solution in stabilizing and reducing greenhouse gases emissions, threatening the environmental integrity of the climate change regime (CCR); nor do they offer a fair and equitable solution to the challenges of global warming. Therefore, it is important that their use remains supplemental to the main goal of reducing and stabilizing green house gases emissions. As a matter of fact, sustainable development could only be achieved if economic efficiency is balanced with environmental integrity and equitable treatment.
\end{abstract}

\footnotetext{
* The author is grateful for the helpful comments of Harro van Asselt and Rodolfo Godínez Rosales to previous versions of this article. Of course, all mistakes remain with the author.

Although this article was finished before the UN Climate Change Conference in Durban (December 2011), the outcome of the Conference has not shed any changes on the article subject; on the contrary, discussion on the fairness and environmental integrity of the Kyoto Flexible Mechanisms are more necessary as ever.
} 
RESUM: El Protocol de Kyoto permet l'ús de tres mecanismes econòmics com a via suplementària per mitigar el canvi climàtic: implementació conjunta, mecanisme de desenvolupament net i comerç d'emissions. Tots tres comparteixen la mateixa ratio, a saber, proporcionar flexibilitat per aconseguir l'acompliment dels objectius d'emissió, tot permetent la reducció d’emissions a un cos mínim mitjançant l'assignació eficient de les responsabilitats entre els agents implicats. Les noves oportunitats de negoci que ofereixen han atret l'atenció dels països més desenvolupats, així com dels emergents. Tanmateix, és dubtós que puguin aportar una solució adequada a l’hora d'estabilitzar i reduir les emissions de gasos d'efecte hivernacle, que amenacen la integritat ambiental del règim del canvi climàtic. Tampoc sembla que ofereixin una solució justa i equitativa per als reptes que planteja l'escalfament global. En conseqüència, és important que el seu ús romangui com a suplementari a l'objectiu principal de reduir i estabilitzar les emissions de gasos d'efecte hivernacle. El desenvolupament sostenible només podria aconseguir-se si l'eficiència econòmica s’equilibrés amb la integritat del medi ambient i un tracte equitatiu.

RESUMEN: El Protocolo de Kyoto permite el uso de tres mecanismos económicos como vía suplementaria para mitigar el cambio climático: implementación conjunta, mecanismo de desarrollo nieto y comercio de emisiones. Los tres comparten la misma ratio, a saber, proporcionar flexibilidad para conseguir el cumplimiento de los objetivos de emisión, permitiendo la reducción de emisiones a un coste mínimo mediante la asignación eficiente de las responsabilidades entre los agentes implicados. Las nuevas oportunidades de negocio que ofrecen han atraído la atención de los países más desarrollados, así como de los emergentes. Sin embargo, es dudoso que puedan aportar una solución adecuada a la hora de estabilizar y reducir las emisiones de gases de efecto invernadero, que amenazan la integridad ambiental del régimen del cambio climático. Tampoco parece que ofrezcan una solución justa y equitativa para los retos que plantea el calentamiento global. En consecuencia, es importante que su uso permanezca como suplementario al objetivo principal de reducir y estabilizar las emisiones de gases de efecto invernadero. El desarrollo sostenible solo podría conseguirse si la eficiencia económica se equilibrara con la integridad del medio ambiente y un trato equitativo. 
KEYWORDS: Kyoto Protocol — Clean Development Mechanism - Emission trading — Fairness — Environmental integrity

PARAULES CLAU: Protocol de Kyoto - Mecanisme de Desenvolupament Net Comerç d'emissions — Justícia — Integritat del medi ambient

PALABRAS CLAVE: Protocolo de Kyoto - Mecanismo de Desarrollo Limpio Comercio de emisiones — Justicia — Integridad del medio ambiente

Contents: I. Introduction. II. Some general considerations on the flexible mechanisms, fairness and environmental integrity. 1. The Rationale of the Kyoto Protocol flexible mechanisms: the cost-efficiency justification. 2. The fairness and environmental integrity imperatives. III. Emission Trading under scrutiny. 1. Nature and functioning of the cap and trade regime. 2. Environmental ineffectiveness of the carbon market. 3. Equity concerns within the carbon market. IV. CDM under scrutiny. 1. Nature and functioning of the CDM. 2. Environmental ineffectiveness of the CDM. 3. Equity concerns and the problem of eco-imperialism. V. Common and general critics to the flexible mechanisms from an environmental and equity point of view. 1. Distraction from the main goal. 2. Privatization of Nature and global commons. 3. Adequacy of the "free market" approach: dichotomy between command and control measures and economic incentives. VI. Conclusions.

\section{INTRODUCTION}

The Kyoto Protocol makes available the use of "economic" mechanisms as a supplementary way of mitigating climate change: “emission trading”, “clean development mechanism" and “joint implementation”. ${ }^{1}$ Although their performance should be additional to the main obligation, which is the reduction of Greenhouse gases (GHGs) emissions through national measures, in the last years many States have enthusiastically participated in those mechanisms -especially in the clean development mechanism-.

\footnotetext{
${ }^{1}$ On the Kyoto flexible mechanism there is a very vast bibliography. An introduction in YAMIN, F. y DEPLEDGE, J., The International Climate Change Regime. A guide to Rules, Institutions and Procedures, Cambridge, University Press, Cambridge, 2004, 136-ff; and an overview of the history on the Kyoto flexible mechanisms in VAN ASSELT, H. \& GUPTA, J., "Stretching too far: developing countries and the role of flexibility mechanisms beyond Kyoto" 28 (2) Stanford Environmental Law Journal, 2009, pp. 311-ff, at 317-31. See also different aspects of the flexible mechanisms in the articles published in specialized reviews such as Carbon and Climate Law Review; available in: http://www.lexxion.de/zeitschriften/fachzeitschriften-englisch/cclr.html (last visited 10/11/2011).
} 
Facing the current negotiations to shape a new and more ambitious climate change regime (CCR), it is convenient to consider if the flexible mechanisms provided by the Kyoto Protocol are suitable and effective to fight climate change in an equitable manner. ${ }^{2}$ If most countries (especially developing ones) do not feel that the future clime regime is fair, they would not be willing to join the negotiations. ${ }^{3}$ In fact, the future climate regime can either bring new opportunities to fight social injustice or remain as an instrument to perpetuate old injustices. ${ }^{4}$

In section 2, I will briefly go over some basic notions concerning the three Kyoto flexible mechanisms and their main rationale, namely cost-efficiency, and I will explain basic ideas on what could be the meaning of fairness and environmental integrity within the climate change regime. Sections 3 and 4 will be dedicated to the critics made against the two most important mechanisms, namely the emission trading and the clean development mechanism. I will consider the critics grouped in those regarding environmental ineffectiveness and those dealing with equity concerns for each mechanism; leaving for section 5 the explanation of some common and general critics applicable to both of them. In the last section I will draw some conclusions.

\section{SOME GENERAL CONSIDERATIONS ON THE FLEXIBLE MECHANISMS, FAIRNESS AND ENVIRONMENTAL INTEGRITY}

\section{The rationale of the Kyoto mechanisms: the cost-efficiency justification}

The most important among the advantages attached to the use of "economic" mechanisms in climate policy is that they provide flexibility to achieve the environmental objective, allowing the reduction of emissions at a minimum cost by

\footnotetext{
${ }^{2}$ Effectiveness and fairness of the CCR has also been widely coped with by international scholars in the last decades, see most recently VIÑUALES, J., "Balancing Effectiveness and Fairness in the Redesign of the Climate Change Regime”, Leiden Journal of International Law, vol. 24, 2011, 223-252.

${ }^{3}$ In a way, these concerns have exacerbated the difficulty to reach an agreement post-Kyoto in the last years, leading to an increase of some countries' reluctance to assume new or even past commitments, as has been newly experimented at the UN Climate Conference in Durban (December, 2011).

${ }^{4}$ SOLTAU affirms that the climate regime "presents the risk of deepening and further perpetuating that unfairness, and simultaneously the prospect of winning a fairer share of global economic and social opportunities” (SOLTAU, F., Fairness in International Climate Change Law and Policy, University Press, Cambridge, 2009, at 137-138).
} 
efficiently allocating the responsibilities between agents (cost-efficiency justification). ${ }^{5}$ Therefore they are also known as "flexible mechanisms".

According to article 17 of the Kyoto Protocol, countries with reduction commitments (Annex I countries ${ }^{6}$ ) are allowed to sell their excess capacity of emissions entitlements to others that will exceed their targets because they could not reduce as much, or find it cheaper to buy those rights than to make direct reductions. ${ }^{7}$ Therefore, this market has created a new commodity in the form of GHG emission reductions, although, being $\mathrm{CO}_{2}$ the most important GHG, one speaks of “carbon emissions” and "carbon market”.

As a complement to emission trading, there are two mechanisms based on the implementation of projects: joint implementation ${ }^{8}$ and clean development mechanism $(\mathrm{CDM})^{9}$, established through articles 6 and 12 of the Kyoto Protocol. They allow countries and their public or private entities to fund projects aimed at reducing source

\footnotetext{
${ }^{5}$ Although HAHN and STAVINS maintain that: "[c]ost can be minimized if all countries use domestic tradable permit systems to meet their national targets and also allow for international trades. But when some countries use non-trading approaches such as greenhouse gas taxes or fixed-quantity standards, cost minimization is not assured" (HAHN, R.W. \& STAVINS, R.N., What Has the Kyoto Protocol Wrought? The Real Architecture of International Tradable Permit Market, The AEI Press Publisher for the American Enterprise Institute, 1999, at 4).

${ }^{6}$ I will not consider here the differences of classifying countries as "Annex I", "non-Annex I", "developing countries", "less-developed" or "emerging countries" facing the rights or obligation they might entail. See on this topic, VIÑUALES, "Balancing...”, cit., at 241-246.

${ }^{7}$ Each Annex I country has an allowed emission divided into "assigned amounts units" (AAUs) that can be sold and purchased in the carbon market. But there is also the possibility to trade with other units such as the removal unit (RMU) on the basis of land use, land-use change and forestry (LULUCF) activities or with the certificates (ERUs and CERs) obtained by the other two flexible mechanisms. Each certificate covers one ton of $\mathrm{CO}_{2}$ or its equivalent in other GHG.
}

The emission trading schemes can be "inter-governmental" (only States take part in the market), "interemission source" (trade is only between emitters) or an "emission source-to-government" (a mixture of the previous two). Article 17 of the Kyoto Protocol only refers to the first type of markets, even if is possible that companies could be associated to their State of origin (but only the State will be responsible). There are also various types of markets at different levels, with the international market created on the basis of the Kyoto Protocol, and the EU Emission Trading Scheme (EU ETS), as a regional market, being the most important ones.

${ }^{8}$ Joint implementation works between two industrialized countries which have reduction commitments under the Kyoto Protocol (Annex I). One of them invests in the other to obtain reductions emission units (ERUs) at a lower cost than if it would have had to reduce them within its borders. The host country benefits from the inversion and the technology provided by the investor.

${ }^{9}$ The CDM involves, on the one side, one industrialized country or a private entity authorized by that State (the investor), and on the other side, one developing country (the host) which does not have reduction commitments under the Kyoto Protocol. The accomplishment of the project in the developing country provides the investor with a certificate -certified emissions reductions or CERs- that can be exchanged for emissions permits in their country of origin or in other countries where it might operate or sell in the carbon market. 
emissions or at increasing the absorption of carbon sinks in other countries, obtaining in exchange carbon credits in order to comply with their commitments. ${ }^{10}$

The theoretical basis to justify that the flexible mechanisms will serve to reduce emissions at a lower cost is that the costs of emissions reduction units differ between companies, regions and, in general, between economic operators. ${ }^{11}$ Indeed, it can be more expensive for a company to make its own investments to abate emissions as compared to investing in projects abroad or purchasing the necessary allowances.

Supposedly, The economic incentive also allows the promotion of new environmentally friendly technologies that reduce emissions, and the possibility to sell the surplus of emission rights. Moreover, the flexible mechanisms offer new business opportunities that have been used as a hook to attract those economies that were more reluctant to assume the costs of climate change mitigation. They also keep the high emitters in the political game, since these mechanisms provide a way to reduce emission with fewer costs (social acceptance element). ${ }^{12}$ In theory, the possibility to reduce emissions cheaper strengthens the willingness to act. In fact, it is generally agreed that without them no Protocol would have ever been adopted, even though it was not followed by the ratification of some States.

However, there are some elements missing in these justifications, which are essential for an adequate climate change regime, namely the non-market goals: environmental effectiveness and the equity/justice elements. It has been affirmed that "cost is not an ethically acceptable excuse for failing to take actions to reduce harmful levels of pollution below the emitting party's fair share of global emissions, particularly when that pollution threatens basic human rights to life, health and security”. ${ }^{13}$ As discussed

\footnotetext{
10 PAREJO NAVAS, T., "Mecanismos de lucha contra el cambio climático en un mercado europeo sostenible”, 20 Revista General de Derecho Europeo, 2010, at 13.

11 There are some studies that prove that without the economic mechanisms, the costs of reduction would be higher. YABAR STERLING, A., "Los mecanismos de flexibilidad de Kioto, otros instrumentos de lucha contra el cambio climático y su aplicación en la Unión Europea”, Observatorio Medioambiental, n. 4, 2001, pp. 307-338, at $328 \mathrm{ff}$.

${ }^{12}$ BROWN, D.A., “Ethical Issues Raised by Carbon Trading”, 15 June 2010.

${ }^{13}$ BROWN, D.A. et al., White Paper on the Ethical Dimensions of Climate Change, The Collaborative Program on the Ethical Dimensions of Climate Change, Rock Ethics Institute, Penn State University, 2006, at 14 .
} 
below, a balance must be achieved between environmental effectiveness, equity and economic efficiency. ${ }^{14}$

\section{The fairness and environmental integrity imperatives}

Notwithstanding the positions sustained by (a few) scholars/scientists either denying the problem of climate change or claiming that is already too late to do something about it, there are good reasons to act against climate change. In the first place, it will be less costly to act now, even as a preventive action, than to do it later. ${ }^{15}$ Furthermore, not to act can be considered as unethical or unjust.

Yet, what is justice? What is to be considered as a fair climate regime? What method of allocation of GHG emissions reduction is equitable? And what time period should we take into account? Are we talking about equity between those who are now alive (inter and intra-country equity) or should we take into account future generations' welfare (inter-generational equity) ${ }^{16}$ There are no clear-cut answers that would satisfy all interests. $^{17}$

However, a preliminary issue,is whether justice or equity should be addressed when designing the future climate international regime. Some authors have stressed that countries need to take into account the equity element and not only their national

\footnotetext{
${ }^{14}$ That is nothing else as the imperative of the sustainable development. This concept has been widely treated in the literature since its introduction at the 1992 Rio Conference on Environmental and Development (Earth Summit). See, i.e., BOYLE, A. and FREESTONE, D., International Law and Sustainable Development: Past Achievements and Future Challenges, Oxford University Press, 1999.

${ }^{15}$ STERN, N., Stern Review on the Economics of Climate Change, UK Treasury, 2006. Likewise, climate activists argue that mitigating climate change would create new jobs and develop new technology, which would lead to economic growth in a sustainable manner (BROWN, D.A., "Stopping the Worst Environmental Disaster?: An Ethical and Scientific Comparison of the Gulf Oil Spill and Climate Change", 25 June 2010). While other pose the question whether it is "possible to make drastic cuts in greenhouse-gas emissions without destroying our economy", although recognizing that there is more and more consensus that what we really cannot afford is no to do anything to mitigate climate change (KRUGMAN, P., "Building a Green Economy”, NY Times, April 5" $5^{\text {th }}$ 2010).

${ }^{16}$ See, for example, the reference to future generations' concerns in art. 3 UNFCCC. On this topic, see generally BROWN WEISS, E., "Climate Change, Intergenerational Equity and International Law", 9 Vermont Journal of Environmental Law, 2008, 615-627.

I will not consider here the rights of non-human beings, although they could also be contemplated from an equity view point.

${ }^{17}$ As it has been sustained, "[w] hat constitutes a fair response to climate change is the main question underlying many of the unresolved issues in the climate change debate". CLAUSSEN, E. \& MCNEILLY, L., "Equity \& Global Climate Change. The Complex Elements of Global Fairness", Pew Centre on Global Climate Change, October $29^{\text {th }} 1998$, at ii.
} 
interests when forming their positions to face international negotiations,. ${ }^{18}$ Not paying attention to ethical reflections leads to significant injustices. The climate change problem is a good example of that.

In fact, climate change policies could exacerbate the existing injustice in the world. On the one hand, those countries that have done least to cause the problem would probably suffer the worst consequences. ${ }^{19}$ Moreover, those most vulnerable to climate change impacts are also the least able to pay for mitigation and adaptation measures. ${ }^{20}$ Even if it was not possible to eradicate all inequities within climate change policies, they should not make them any worse. ${ }^{21}$

On the other hand, developing countries (mostly emerging countries) claim their right to develop notwithstanding the climate change problem, since it was not created by them. This has full consideration in the actual climate change regime (e.g. art. 3.1 and 3.2 UNFCCC), namely only industrialized countries are committed to reduce concrete GHG emissions or provide financial and technical support, among other obligations towards developing countries (art. 11 UNFCCC).

Therefore, the future post-Kyoto regime has to comply with two indispensable criteria: environmental integrity and fairness. Otherwise it will be very difficult to rejoin all countries into feasible and appropriate international negotiations facing the design of a future climate change regime ${ }^{22}$

The environmental integrity criteria require the assurance of sufficient GHG emission reductions in order to keep below a safe temperature level. According to article 2 of the UNFCCC, the goal is to stabilize GHG concentrations in the atmosphere "at a level that would prevent dangerous anthropogenic interference with the climate system”, and that "[s]uch a level should be achieved within a time frame sufficient to allow ecosystems to

\footnotetext{
${ }^{18}$ BROWN, D.A., Minimum Ethical Criteria For All Post-Kyoto Regime Proposals: What Does Ethics Require of A Copenhagen Outcome, ClimateEthics.org, 2008.

19 Some authors affirm that, on an equity basis, "no individual should be denied the possibility of surviving climatic change because of their poverty, race, class, gender, religion or geographical location”. MEYER, A. \& HILDYARD, N., “Climate and Equity after Kyoto”, 03 The Corner House Briefing, December 1997.

${ }^{20}$ BROWN et al., White Paper..., cit., at 10.

${ }^{21}$ CLAUSSEN \& MCNEILLY, “Equity...”, cit., at 19.

${ }^{22}$ Among other reasons, the Montreal Protocol was successful because it encloses the implementation of equity principles that encouraged the participation of developing countries (CAZORLA, M. \& TOMAN, M., "International Equity and Climate Change Policy” 27 Climate Issue Brief, 2000, at 6.
} 
adapt naturally to climate change, to ensure that food production is not threatened and to enable economic development to proceed in a sustainable manner”. According to the IPCC reports an increase of $2^{\circ} \mathrm{C}$ over the present temperature could lead to

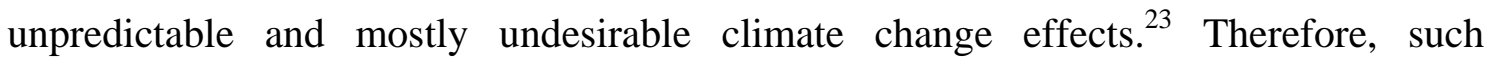
reduction threshold could work not only as warranty of equity between nations, but also between generations.

Each Annex I country has agreed to reduce a certain amount of GHGs during the period 2008-2012. A global ceiling of emissions has not been established, even though that would normally constitute a first step in the process of allocating emission burdens to reach the environmental goal of mitigating climate change. ${ }^{24}$ It is also well-known that the Kyoto Protocol targets are far below of what is necessary to stabilize the climate change.

The equity criteria require that those reductions should be distributed or allocated on a fair basis. In this sense, there are some parameters that have been suggested in order to distribute the national allocation of GHG reductions, ${ }^{25}$ such as the "per capita" and the "historical contribution” proposals.

The "per capita" proposal is based on the assertion that all human beings are equal. Thus, they should all be entitled to an equal share of atmospheric commons. This argument clearly benefits developing countries with large populations, such as India or China. ${ }^{26}$ From a justice point of view this is acceptable, but it is doubtful whether it could satisfy the environmental integrity requirement. In fact, the quickly increasing

\footnotetext{
${ }^{23}$ Intergovernmental Panel of Climate Change, Summary for Policymakers of the Synthesis Report of the IPCC Fourth Assessment Report, IPCC, Geneva, November 2007.

${ }^{24}$ However, Art. 3.1 of the Kyoto Protocol provides,an approximation of a global cap by establishing that Annex I parties overall emissions of GHG should sink "by at least 5 per cent below 1990 levels...”. Nevertheless, as some authors point out, if the long-term objective remains non-quantified, it will be difficult to determinate "whether the shorter targets adopted [...] are in line with the overall objective" (VAN ASSELT \& GUPTA, “Stretching too far...”, cit., at 320).

${ }^{25}$ See an overview of these and other parameters in BROWN, Minimum Ethical..., cit., and BROWN et al., White Paper..., cit., at 8 and ff. and in VIÑUALES, "Balancing...”, cit., at 234-236 and 246-251.

As VIÑUALES rightly states, not all parameters are adequate to address the different rights and obligations settled within the CCR. While some could be useful to define the burden of reducing emissions, others could be necessary to establish the obligation to contribute to financial and technological assistance (ibid., at 252).

${ }^{26}$ Some developed countries as the US have a per capita emission rate of 6 times more than China or 13 times more than India (SOLTAU, Fairness..., cit., at 8). Although, as it has been stated, "China and India would be able to increase their national emissions significantly before reaching their population-toemissions ration limit because of their large and rapidly growing populations and rapid economic growth" (CAZORLA \& TOMAN, "International Equity...”, cit., at 10).
} 
populations and the rapid economic growth of some countries will significantly increase their national emissions, and still not surpass the per capita emissions rate of some other developed countries.

For the same token, other criteria could also be considered in order to allocate GHG emissions reductions, such as the geographic and climatic conditions of some countries and regions, or the energy intensity of their economies. ${ }^{27}$

In this sense, the per capita proposal could be complemented with the "satisfaction of basic needs” criteria, allowing some nations to emit GHG in an amount that guarantees those basic needs, whilst other will have to reduce their emissions because their levels exceed by far what is required to satisfy the basic human needs. The main point is to differentiate between "survival” and "luxury" emissions. ${ }^{28}$

Industrialized countries should reduce the occupation of ecological space in favor of developing countries. In fact, the contraction and convergence theory specifies that while industrial countries will have to reduce resource flows (contraction), developing countries will raise their levels of resource consumption, but at a smaller grade than industrialized countries did historically, so developed and developing countries would converge to the same per capita emission ratio (convergence). ${ }^{29}$ This criterion is also linked to the question of guaranteeing fundamental human rights which everyone should enjoy, such as the rights to life, liberty and personal security. ${ }^{30}$

According to the "historical contribution" proposal, countries will be asked to account for past GHG emissions that have generated global warming, either by making greater efforts to reduce GHG emissions or by assuming the cost of other nation's reductions. This can also be seen as a materialization of the "polluter pays" principle. ${ }^{31}$ Industrialized countries do not usually agree with this approach and try to make "status

\footnotetext{
${ }^{27}$ OTT, H., \& SACHS, W., Ethical Aspects of Emissions Trading, Wuppertal Institute, 2000, at 13.

${ }^{28}$ SHUE, H., "Subsistence Emissions and Luxury Emissions", Law and Policy, vol. 15, 1993, at 39; VANDERHEIDEN, S., Atmospheric Justice: A Political Theory of Climate Change, 2008, at 47.

${ }^{29}$ OTT \& SACH, Ethical Aspects..., cit., at 10; CAZORLA \& TOMAN, “International Equity...”, cit., at 9.

${ }^{30}$ BROWN et al., White Paper..., cit., at 9. It is also important having a fair domestic distribution of the emission entitlements in order to assure those rights to the whole population (VIÑUALES, "Balancing...", cit., at 250).

${ }^{31}$ See further on this principle below in section 3.
} 
quo” proposals so current emissions are recognized as entitlements. ${ }^{32}$ This claim poses many doubts due to the global common nature of the atmosphere, but also from an equity view point. In this sense, who has the right to use the biosphere as a global carbon sink $\mathrm{k}^{33}$ and in which amount? ${ }^{34}$ Those who want to take greater advantage of it need a justification which is not immoral or unjust.

The aforementioned considerations are important from a justice point of view, but it can endanger the environmental integrity if non-industrialized ones use them as a justification for not undertaking any effort to mitigate climate change. We shall not forget that present and future emissions, even justified on an equity basis, will still be unjust for future generations or less-developed countries, ${ }^{35}$ especially when we now know that emitting GHGs into the atmosphere can have perverse effects. According to some authors, "[e]quity also presupposes [...] that everyone takes responsibility for keeping their future emissions within ecological limits”. ${ }^{36}$ Yet, earlier GHG emissions reductions efforts of emerging countries should also be considered when setting their reduction commitments.

Whatever the chosen parameter, one thing is clear: the burden of mitigation is on the industrialized countries, which are responsible for the majority of past and present emissions. It is important that poor countries or populations do not bear a heavier burden than industrialized or wealthier ones. That is so taking into account their historical responsibilities for causing the existing problem, but also their ability to pay

\footnotetext{
${ }^{32}$ As DUBASH puts it: "industrialized countries construct the problem around what they see as pragmatic politics aimed at changing future emissions trends rather than around principles to redress past wrongs". DUBASH, N., "Copenhagen: Climate of Mistrust”, 52 Economic\& Political Weekly, vol. XLV, 2009, at 9 .

33 According to art. 1.8 UNFCCC a "sink" is a "process, activity or mechanism which removes a greenhouse gas, an aerosol or a precursor of a greenhouse gas from the atmosphere”.

${ }^{34}$ BROWN et al., White Paper..., cit., at 10.

${ }^{35}$ It has been affirmed that the "polluter pays principle" should include "not only who emitted the most in the past, but also who will emit the most in the future” (CLAUSSEN \& MCNEILLY, "Equity...”, cit., at 1).
}

As VIÑUALES notes: “Given the projected emissions of a number of developing countries, especially emerging economies, their contribution to the global mitigation appears indeed indispensable to stabilize GHG concentrations in the atmosphere at an acceptable level. Without such contribution, the 'historicalemissions' criterion would yield unfair results, because those developing countries that are more vulnerable to the consequences of climate change would suffer disproportionally to accommodate the interests of emerging economies.” (id., "Balancing...”, cit., p. 247).

${ }^{36}$ MEYER \& HILDYARD, “Climate...”, cit. Here we find a link between environmental integrity and equity, what is not always so, as seen before. 
for it. ${ }^{37}$ As BROWN asserts, “distributive justice does not always require completely equal distributions", although the "basis for being treated differently is based on morally relevant criteria”. 38

Most of these elements are included in the principle of common but differentiated responsibilities, ${ }^{39}$ also acknowledged within the international climate regime. ${ }^{40}$ This principle, declared as the "cornerstone" of the climate regime, materializes and gives effect to equity and fairness. ${ }^{41}$

Thus, it is necessary to take a careful look at each mechanism in order to consider its legitimacy from a fairness and environmental integrity point of view. The crucial element is to know if the considered flexible mechanisms are adequate to mitigate climate change on a fair basis. In order to shed more light on this, I will focus my attention on the CDM and the cap and trade regime, based on the European experience. $^{42}$

\footnotetext{
${ }^{37}$ In this sense, States can be classified as those that (i) must act now; (ii) should act now, but differently; and (iii) could act now if feasible. CLAUSSEN \& MCNEILLY, "Equity...”, cit., at ii.

${ }^{38}$ BROWN, Minimum Ethical..., cit.

${ }^{39}$ On this topic see generally, RAJAMANI, L., Differential Treatment in International Environmental Law, Oxford University Press, 2006.

${ }^{40}$ Although there is still substantial disagreement about how to understand and apply the principle of common but differentiate responsibilities within the climate regime (RAJAMANI, L., "Neither Fish nor Fowl”, Seminar 606, February, 2010, at 29).
}

DUBASH also refers to the deep mistrust existing between industrialized and developing countries in this matter (id., "Copenhagen...”, cit., at $8 \mathrm{ff}$ ). In fact, developing countries use this principle for "rejecting binding commitments, asserting that the historical responsibility for climate change was not theirs, that they had less financial ability to pay for reductions, and that they had more urgent priorities for their limited resources", whereas developed countries have assumed this principle but also want to settle when some emerging countries will start to assume greater responsibilities because "developing countries are likely to be the primary industrial emitters in the future" (CAZORLA \& TOMAN, "International Equity...", cit., at 1-2).

${ }^{41}$ SOLTAU, Fairness..., cit., at 225 and 263.

${ }^{42}$ With the objective of complying with the Kyoto Protocol's commitments and with the goal of coordinating with the international market created in 2008, the EU was a pioneer by the establishment of an emission trade scheme in 2005. It follows the "cap and trade" system, and it is open to some emitters (companies and installations), but also to all types of individuals and private persons. Paradigmatically, the UE opposed at the beginning this flexibility during the negotiations of the Kyoto Protocol, and it turned to be the main proponent of the instrument (VAN ASSELT \& GUPTA, "Stretching too far...", cit., at 336). 


\section{THE EMISSION TRADING UNDER SCRUTINY}

\section{Nature and functioning of the cap and trade regime}

A cap and trade regime consists of establishing a legal limit on emissions -the cap- in a certain time period within a region, country or group of States. For example, within the EU Emission Trading System, industries and other emitters are allowed to pollute up to a certain amount of carbon permits or emissions allowances that they hold. Those allowances are usually granted for free based on their historical emissions (grandfathering), but to a certain limit, which will be lower as time passes. ${ }^{43}$

The total amount of the quotas assigned to States and installations that participate in the plan represents the allowed global limit. This global limit is the supposed environmental benefit of the plan. Since the allowances are scarce, each would have a price that will encourage the participants in the scheme to implement measures in order to reduce emissions.

The "trade" element comes when industries need more carbon permits than allowed because they still depend on fossil and carbon energy to carry on with their activities. Then, they can buy the surplus from other companies that have reduced their emissions, due to, for example, the use of renewable energy sources.

The cap and trade mechanism is therefore a mixed instrument since it provides State intervention while setting the emissions limit (the cap element), and accepts the action of the free market when providing flexibility by the accomplishment of the cap (the trade element).

As already mentioned, the objective of the trade system is allowing emitters to meet their commitments at a lower cost. Yet, what is cheap is not always environmentally effective or socially just. Cost-efficiency cannot constitute the sole element to inform climate change policy. Moreover, it should be secondary, facing the two other more important elements already mentioned: environmental integrity and equity. Yet, there are serious doubts about whether these two elements are really taken into account, as will be shown below.

\footnotetext{
43 See Directive 2003/87/EC and its posterior revisions; available at: http://ec.europa.eu/clima/documentation/ets/index_en.htm (last visited: 10/11/2011).
} 


\section{Environmental ineffectiveness of the carbon market}

\subsection{The environmental element of the cap and trade scheme}

The fact of setting a cap and allowing the trade of the distributed allowances is the manifestation of the "polluter pays" principle, since the one emitting is paying for it. ${ }^{44}$ Emissions must be considered while doing business, since they are visible on the balance sheet alongside other assets. This internalizes the costs that the community should otherwise assume.

Nevertheless, the cap and trade scheme does not have as a direct aim the reduction of GHG emissions; it only allows to trade with allowances and carbon offsets that have supposedly reduced carbon emissions somewhere else. It does not reduce per se the emissions, but it relocates them. It does not have a direct environmental impact, but it helps to comply with environmental public laws. Thus, it cannot be by itself but as a complement of the regulatory power.

Neither does the carbon market lead to production methods based on energy sources other than fossil fuels. In fact, the search of cheap ways to reduce emission leads to patch up traditional power stations and factories, leaving the substantial changes for the future (referred as the "locking in pollution problem”). ${ }^{45}$

The only element that has a positive environmental effect is the cap (of regulatory nature), while the trade element has a pure economic value and can only indirectly be considered an environmental technique. ${ }^{46}$ Therefore, in order to be environmentally effective, a total amount of reduction has to be settled on an international basis, and then redistributed between those countries that should make reductions. Yet, the cap settlement brings some controversies, as we will see below.

\footnotetext{
${ }^{44}$ SANZ RUBIALES, I. (Dir.), El Mercado de derechos a contaminar. Régimen jurídico-público del mercado comunitario de derechos de emisión en España, Lex Nova, Valladolid, 2007, at 103-ff.

Although it has been affirmed that this principle is "easier to implement with discrete environmental problems, such as an oil spill or a toxic release, where it is relatively easy to identify a small number of polluters. When the environmental problem is more continuous (e.g. the polluters will continue to pollute in the future, but perhaps at a lower level) or where everyone is a polluter and has been for an extended period of time, this principle can still be applied [...]; when more than one person is contributing to the problem, it may be fair to consider who has the resources to address the problem, or who could do so at lower cost.” (CLAUSSEN \& MCNEILLY, “Equity...”, cit., at 13).

45 Some examples in CARBON TRADE WATCH, "Carbon Trading - How it Works and Why it Fails" (Chapter 4), Critical Currents no. 7, November 2009).

46 SANZ RUBIALES, El Mercado..., cit., at 89; GILBERTSON, T. \& REYES, O., "Carbon Trading. How it works and why it fails”, 7 Critical Currents, Dag Hammarksjöld Foundation, Uppsala, 2009, at 10 .
} 


\subsection{Problems with setting and distributing the cap}

The cap has the function of limiting the emissions by creating scarcity of emission entitlements, so industries or countries need to reduce them or turn to the market to buy emissions rights.

The cap has to be as tight as possible in order to guarantee the environment integrity of the cap and trade regime. The cap is also supposed to diminish over the years, so the cost of the allowance will increase gradually. However, since trade depends on surplus of emissions, the cap cannot be as tight as environmental protection would require. Therefore, there is a risk of companies increasing their emissions while remaining within the cap.

The EU ETS is a good example of that. ${ }^{47}$ In its Phase I (2005-2007) the initial caps were calculated using the projections of historical emissions (the "grandfathering” approach) provided by the Member States based on their industries emissions. The emissions turned out to be much lower than the permits given. ${ }^{48}$ The generous allocation of allowances granted for free to national installations generated an oversupply of allowances that motivated the dropping to almost zero of the carbon prize in 2007. It did not lead to emission reductions and undermined the environmental objective of the mechanism. Certainly, if there are more tradable permits than needed, it is very difficult to accomplish a real reduction, as there are no incentives to reduce or to buy permits.

In Phase II (2008-2012) of the EU ETS some tightening took place, as the Commission reviewed the reduction ceiling settled by the Member States. Nevertheless, the free allocation of allowances, the use of the Kyoto flexible mechanisms (offsets) ${ }^{49}$ and the surplus of emission permits of some Central and Eastern Europe countries due to their economic collapse ("hot air") ${ }^{50}$, made it possible for installations to meet their mandatory cap with no abatement efforts and generated new price fluctuations of carbon permits. $^{51}$

\footnotetext{
${ }^{47}$ A comprehensive study of this scheme in VAN ASSELT, H., "Emissions trading: the enthusiastic adoption of an alien instrument?", in Jordan, A. et al. (eds.) Climate Change Policy in the European Union: Confronting the Dilemmas of Mitigation and Adaptation?, 2010, at 125. For a critical view, GILBERTSON \& REYES, “Carbon Trading...”, cit., at 31-ff.

${ }^{48}$ VAN ASSELT, “Emissions trading...”, cit., at 129.

${ }^{49}$ It is possible through the adoption of the "Linking Directive" (2004/101/EC).

${ }^{50}$ GILBERTSON \& REYES, “Carbon Trading...”, cit., at 32.

${ }^{51} \mathrm{Ibid}$., at $39 \mathrm{ff}$.
} 
For Phase III (2013-2020) of the EU ETS the use of offsets will be limited, and the free allocation of permits will gradually shift towards an auctioning system, ${ }^{52}$ which will better match the real objective of the carbon market. ${ }^{53}$ However, as companies will be allowed to use the permits of phase II (banking), the surplus of permits is warranted. ${ }^{54}$ Besides, the EU climate and energy package allows that half of the EU's carbon reductions for 2020 will come from offsetting. ${ }^{55}$

Nonetheless, there is some suspicion with the idea that tightening the cap and having a high carbon price will lead to GHG reductions or to the shift of productions patterns away from fossil fuel dependency. As a matter of fact, previous crises of oil prices have not led to renounce it as an energy source. ${ }^{56}$ Besides, it has been asserted that if prices are so high to threaten the system, the emission trading scheme will be altered or abandoned. ${ }^{57}$

\section{Equity concerns within the carbon market}

\subsection{Fairness by setting and distributing the cap}

In order to check if the cap is just, one has to look at the amount of the cap and how this cap is distributed among emitters. The question is which is the fair share of global emissions attributed to each country? Are the reduction commitments in the Kyoto Protocol settled on an equity basis? Should the emissions of developing countries, particularly emerging countries, be limited?

It has been sustained that the cap of a country has to meet that country's GHG reduction obligation (which also has to be its fair share of global emissions) in order to be just. ${ }^{58}$ Yet, no one has the right to decide which GHG level in the atmosphere is tolerable

\footnotetext{
${ }^{52}$ Although, those sectors at risk of carbon leakage will still have free allocation of allowances since they cannot pass the costs incurred to the customers.

${ }^{53}$ See Directive 2009/29/EC, which revised the Directive 2003/87/EC.

${ }^{54}$ GILBERTSON \& REYES, “Carbon Trading...”, cit., at $44 \mathrm{ff}$.

${ }^{55}$ BULLOCK, S., CHILDS, M., \& PICKEN, T., A Dangerous Distraction. Why Offsetting is Failing the Climate and People: The Evidence, Friends of the Earth, June 2009, at 8-9. Therefore, the commitment undertaken by the EU to reduce by $20 \%$ by 2020 , will only be a $10 \%$ effective reduction.

${ }^{56}$ LOHMANN, L., "When Markets are Poison. Learning about Climate Policy from the Financial Crisis", (2009a) 40 The Corner House Briefing, September, 2009, at 35.

${ }^{57}$ Ibid.

${ }^{58}$ BROWN, “Ethical Issues...”, cit.
} 
without consulting those who would most likely suffer greater climate change damages. The settlement of a cap that does not prevent dangerous anthropogenic interferences is unjust "to those who are most vulnerable to climate change". 59 Therefore, if the most vulnerable have the right to decide, the conclusion is that "atmospheric levels of GHGs should be stabilized at the lowest possible levels above existing atmospheric GHG concentrations". ${ }^{60}$ Here, we find that the equity requirement meets the environmental goal.

Regarding the distribution of the cap, parameters such as "historical responsibility" and the "per capita" criteria, which are important to allocate the GHG reductions within countries, have already been examined. ${ }^{61}$ Here it is important to highlight that, from an environmental point of view and, therefore, also from as an equity mandate, all large emitters (past, present and future) should take some reductions commitments. ${ }^{62}$ However, as has already been discussed, it is also an imperative of justice that developed countries take the lead in reducing GHG emissions (principle of meaningful industrialized country leadership).

The allocation of carbon permits within a country can also raise equity concerns. Either auctioned or given for free, those permits will usually favor the most wealthy and monopolistic industries. Here we have to notice that certain transnational corporations are responsible for more emissions than some States. It has also been criticized that several companies have passed on the costs of reducing emissions to their costumers, even though they received their allowances for free (leading to windfall effect profits). ${ }^{63}$

These criticisms are also connected to problems of procedural justice. Not everyone within the international community or within the countries has the opportunity to participate in decisions that might affect them. ${ }^{64}$ The complexity and technicality of a

\footnotetext{
${ }^{59}$ Ibid. he further says: "a cap that is not sufficiently environmentally protective is unjust to these vulnerable countries and peoples”.

${ }^{60}$ BROWN et al., White Paper..., cit., at 18. Elsewhere, BROWN also affirms that elevated GHG concentrations in the atmosphere "would only be ethically legitimate policy options if those most vulnerable to climate change impacts consented to be put at risk" (id., Minimum Ethical..., cit.).

${ }^{61}$ See section 2.

${ }^{62}$ According to some authors, "no person or nation has a right either to harm others as a mean to achieve their economic health or to endanger others' life, health, or security" (BROWN et al., White Paper..., cit., at 30). OTT and SACH also point out that the absence of caps for developing countries would lead to ecological perverse results (id., Ethical Aspects..., cit. at 16).

${ }^{63}$ VAN ASSELT, “Emission Trading...”, cit., at 136.

${ }^{64}$ See more on this in BROWN et al., White Paper..., cit., at 18.
} 
cap and trade regime excludes also those who do not have the financial resources to get some expert advice in order to take part in the design of such models.

\subsection{Green-protectionism? Trade and competitiveness}

Another problem of cap and trade schemes is that they grant developed states a new commercial instrument to protect their productions. In fact, to prevent the loss of competitiveness of first world companies resulting from higher costs due to their emissions, some developed countries have discussed the adoption of "border carbon adjustments” (BCA) that will oblige importers to pay equivalent emission rights in order to import their products in the first world markets. The BCA will be probably applied to those importers from countries that do not have a comparable climate policy, mostly developing countries.

The grandfathering of allowances and its granting free-of-charge to domestic installations and companies are a way of reducing problems of competitiveness but an unjust option in case of imposing BCA to products manufactured in developing countries. These free allowances are subsidies capable of distorting trade. However, there is the fear that not giving permits for free or reducing the cap would lead to relocation of their plants in other countries with less stringent carbon regulation, therefore creating the problem of carbon leakage. ${ }^{65}$

Developing countries consider this as an example of green protectionism and a way of shifting responsibilities in climate and bringing injustice in an already unjust situation.

That shows that climate change is an environmental problem, but it has also great effects on international trade and competiveness. As some authors affirm, "no environmental issue has ever had more implications for trade than climate change". ${ }^{66}$ It could contradict WTO rules but, above all, it is very doubtful that it could be compatible

\footnotetext{
${ }^{65}$ CARBON TRADE WATCH, “Carbon Trading...”, cit.

${ }^{66}$ MELÉNDEZ-ORTIZ, R. et al., "Anticipating Pressing Issues in Integration: The Trade, Climate and Sustainable Developing Nexus”, 14 (30) Institute for the Integration of Latin America and the Caribbean, 2010, pp. 21-32, at 21.
} 
with the principle of common but differentiated responsibilities, whose observance is vital for a fair international climate change regime. ${ }^{67}$

\section{THE CDM UNDER SCRUTINY}

\section{Nature and functioning of the CDM}

Of the two Kyoto flexible mechanisms based in projects, the CDM is the larger offsetting scheme. ${ }^{68}$ Emissions offsets generated by CDM have to be accredited by the UNFCCC in order to be used as carbon credit, and be tradable in the different emission trading schemes.

The CDM is presented as a "win-win-win" situation, since it provides developing host countries with investments that will help them to achieve a sustainable development, while industrialized countries (or their industries) can meet their reduction targets with the allowances they reach through the fulfillment of those projects. The other "winner" is supposedly the environment.

Whereas for developed countries it means a reduction of emissions at a lower price, for developing countries it means receiving capital investment, clean technology or beneficial change in land use, as the projects usually deal with renewable energy, methane abatement, energy efficiency, reforestation or fuel switching. ${ }^{69}$ Therefore, it has been said that CDM projects lead to improvements of life quality for local populations (decrease of pollution, safety for women, and better education for children, as well as better preservation of forests having as benefits the use of less carbonintensive fuel). ${ }^{70}$ However, this assertion is valid only in theory, as it will be shown below.

\footnotetext{
${ }^{67}$ Further on this topic see FERNÁNDEZ EGEA, R.M. \& SINDICO, F., "Cambio climático y comercio: su dimensión norte-sur”, Revista de la Facultad de Derecho de la Universidad de Granada, vol. 12, 2008, pp. 223-260.

${ }^{68}$ By mid-November 2011 there are over 3,500 registered projects and more than 770 million CERs have been issued. See http://cdm.unfccc.int/index.html (last visited: 10/11/2011). The UNEP estimates that between 2009 and 2020, over 5 billion CERs will be issued. BULLOCK et al., A Dangerous..., cit., at 11.

${ }^{69}$ The CDM is seen as a direct emanation of the common but differentiate responsibilities principle since "it is based on a partnership between developing and industrial countries, with differing commitments under the climate regime, to solve a global problem" (RAJAMANI, Differential Treatment..., cit., at 244).

${ }^{70}$ For this reason, it is also called "mechanism of cooperative implementation" (KEULARTZ, J., "Kyoto and the Ethics of Flexibility”, in Vermeersch, E. (ed.), Reading the Kyoto Protocol. Ethical Aspects of the Convention on Climate Change, Eburon Academic Publishers, 2005, at 144).
} 


\section{Environmental ineffectiveness of the CDM}

\subsection{Permanence and "additionality" of the carbon reductions}

One of the most important problems of the CDM is that the permanence of carbon reduction is not always assured. Some projects used for offsetting cannot guarantee the carbon reduction they are supposed to cause, and there are problems in proving that. Carbon captured in forests is a good example of that, because even if trees serve as carbon sinks, they could release $\mathrm{CO}_{2}$ to the atmosphere in case of fire or if they died due to a rapid temperature rise. ${ }^{71}$

Besides, the emission reductions of the CDM projects have to be additional to what would have happened anyway. Projects will not comply with the "additionality" principle if the emissions reductions take place in their absence (in the "business as usual” scenario).

The problem is that CDM usually deals with potential emissions that have not taken place yet. The offsets cuts are created with hypothetical "business as usual” baselines. Therefore, the emissions reduction is fully speculative, since it turns supposed future results into bankable carbon credits. ${ }^{72}$ There is also some evidence that the technology applied in most CDM projects was already a common practice in developing countries ${ }^{73}$ or projects that had already been initiated. ${ }^{74}$

In practice, there is an undeniable incongruence between the environmental goal of setting a cap, and trade schemes and carbon offsets, since offsets projects are an authorization to print new emission permits. ${ }^{75}$ They could also lead to perverse consequences, as they incentivize more emissions if countries establish a high emission

\footnotetext{
71 Against the tree-planting projects for carbon offsetting purposes see LOHMANN, L., "The Dyson Effect. Carbon "Offset” Forestry and the Privatization of the Atmosphere”, 15 The Corner House Briefing 2009. He sees many inconveniences in promoting forests as carbon sinks in order to serve as offsets.

${ }^{72}$ They face the same problems as the derivative markets in the financial world since they share the same structure (GILBERTSON \& REYES, “Carbon Trading...”, cit., at 51).

${ }^{73}$ For example, the growth plans for hydro-electricity in China would have taken place also in the absence of CDM projects (BULLOCK et al., A Dangerous..., cit., at 13-15.

${ }^{74}$ In November 2007 35\% of all 654 hydro projects were completed before their final registration (TREIBER, M., “Clean Development Mechanism: A Symbolic Action?” UMB Student Journal of International Environment and Development Studies, vol. 1, 2011, at. 40, citing HAYA, B. Failed mechanism-How the CDM is subsidizing hydro developers and harming the Kyoto Protocol, International Rivers, November 2007). See other examples in GILBERTSON \& REYES, “Carbon Trading...”, cit., at 54-ff.

${ }^{75}$ BULLOCK et al., A Dangerous..., cit., at 16.
} 
baseline, especially developing countries not subject to reductions commitments and willing to sell reductions as offsets. ${ }^{76}$ Therefore, the environmental integrity of these projects is doubtful. 77 "Additionality” is not always assured, and still, offset credits are considered identical to emission reductions. ${ }^{78}$

Regarding the CDM environmental integrity, the fact that there are great difficulties in monitoring and verifying its functioning is also problematic. ${ }^{79}$ Together with the permanence and "additionality" of reductions, it is also necessary to prove that the performing of CDM projects does not cause emissions somewhere else, in other words, that it does not create carbon leakage. Nevertheless, all these elements are really difficult to calculate, and sometimes it is virtually impossible to measure and obtain the data needed to verify the environmental effectiveness of a measure.

For example, many authors also affirm that it is impossible to certify "additionality" ${ }^{80}$ In fact, in order to prove it, one needs to settle the emissions that would have taken place without the project, and to measure the actual emissions after finalizing the project. So, it is proved by comparing the emissions with and without the project but without testing if the project would have taken place in absence of the CDM. ${ }^{81}$ Besides, since CDM projects are carried out over decades, it is uncertain what emission reductions should be made.

Monitoring is also complex while making comparative or equivalent different economic and industrial practices in the different countries, sometimes with disparities in the

76 http://www.guardian.co.uk/environment/2008/may/26/climatechange.greenpolitics (last visited: 10/11/2011).

${ }^{77}$ As SOLTAU notes, since "it is not possible to ensure that every credit from an offset mechanism like the CDM represents a real, measurable, and long-term reduction in emissions, the use of carbon offsets in a cap-and-trade system can potentially undermine the system’s integrity” (id., Fairness..., cit., at 81-82).

${ }^{78}$ As LOHMAN points out: “Articles 3 and 12 of the Kyoto Protocol stipulate, without argument, that these offset credits are identical with emissions reductions” (id., "When Markets...”, cit., at 29).

${ }^{79}$ BROWN, “Ethical Issues...”, cit.

The CDM Executive Board is in charge of allowing the projects, yet it is under-staffed and there is a "bottle neck" of projects to be verified. Interest countries (developed and developing countries) exercise a lot of pressure to speed up the approval process. Often, the CDM Executive Board requires external help of verifiers, who are paid by the projects developers. Therefore, it is very common that CDM are approved (BULLOCK et al., A Dangerous..., cit., at 15).

${ }^{80}$ BULLOCK et al., A Dangerous..., cit., at 4; VAN ASSELT \& GUPTA, “Stretching too far...”, cit., at $344 \mathrm{ff}$.

${ }^{81}$ VAN ASSELT \& GUPTA, “Stretching too far...”, cit., at 344. That is also due to the pressure exercised by installations and host countries willing to develop a CDM project. 
methodologies used, in order that commodities could be exchanged in the market. ${ }^{82}$ The problem is exacerbated if the host country does not have the technical instruments to monitor or verify these elements. In fact, the credibility of some certification providers is questioned. ${ }^{83}$ This difficulty is also linked to the enforcement problem, to which little money is being destined.

In this sense, due to the monitoring, verification and enforcement problems, and in order to decrease their costs, the data would not be as accurate as it should, and credits would be issued anyway. ${ }^{84}$

\subsection{The "clean" nature of the projects}

It is also doubtful that projects being funded are really "clean" or that they lead to a transition to a non-fossil dependent society. ${ }^{85}$ Some are not that environmental friendly or have other important social implications.

It has been sustained that CDM is a way to stream high polluters to the third world, and to avoid industries and developed States changing their industrial practices and energy use. ${ }^{86}$ Moreover, many of these projects have little to do with addressing the fossil fuel question. ${ }^{87}$ In fact, instead of encouraging and transferring innovative renewable energy technologies, ${ }^{88}$ most CDM projects strengthen established industrial interests, including fossil fuel interests. Actually, in LOHMANN'S words, "these are precisely the projects that would appear to make the least contribution to the systemic social and infrastructure transformation needed for phasing out fossil fuels" ${ }^{89}$ Thus offsetting

\footnotetext{
${ }^{82}$ CARBON TRADE WATCH, “Carbon Offsets”, December 2009. For example, it is not comparable to burn more coal and build more hydro-electric dams, or to plant monoculture tree plantation and capture methane in coal mines.

${ }^{83}$ LOHMANN, “The Dyson Effect...”, cit., at 49.

${ }^{84}$ According to TREIBER "The lack of formal definition, objective monitoring and ex-post evaluation, allows the scope for corruption, manipulation and conspiracy between actors, compromising the effectiveness and efficiency of the system" (id., "Clean Development...", cit., at 42).

${ }^{85}$ Some evidence of this in GILBERTSON \& REYES, “Carbon Trading...”, cit., at 53-ff.

${ }^{86}$ Ibid., at 11-12.

${ }^{87}$ LOHMANN, "When Markets...", cit., at 42-43. As affirmed by GILBERTSON and REYES, "As of September 2009, three-quarters of the offset credits issued were manufactured by large firms making minor technical adjustments at a few industrial installations to eliminate hydro fluorocarbons (HFCs) and nitrous oxide (N2O)” (id., "Carbon Trading...", cit., at 54).

${ }^{88}$ Only in 39\% of the CDM projects technology transfers takes place (SOLTAU, Fairness..., cit., at 83 ).

${ }^{89}$ Ibid., at 44.
} 
work becomes a non-incentive to take the urgent action needed to avoid high-carbon infrastructure investments. ${ }^{90}$

Another example of the environmental adverse effects of the CDM projects is that the destruction of industrial pollutants is also suitable for offsetting. In fact, the largest number of credits under the CDM does not come from projects aiming to reduce $\mathrm{CO}_{2}$ by shifting to energy efficiency technologies, but from reducing another GHG used in refrigerators -hydro fluorocarbons or HFCs-, which are cheaper and easier to be eliminated since their capture and destruction can be accomplished with minor technical adjustments. ${ }^{91}$ In these sense, some emerging countries (such as India or China) opposed the suggestion to phase out such pollutants -which also deplete the ozone layer- under the Montreal Protocol, since it would eliminate the possibility of hosting projects directed to eliminate them under the Kyoto Protocol. ${ }^{92}$

In fact, the incentives of offsetting are not creating climate solutions but inventing new ways of emission reductions equivalents. ${ }^{93}$

\section{Equity concerns and the problem of eco-imperialism}

\subsection{Eco-imperialism and the social and environmental adverse effects of CDM projects}

CDM projects impede host countries to implement environmental measures by their own, because otherwise potential revenue would be cut off (regulatory chill). ${ }^{94}$ If they start to implement environmental legislation in order to reduce emissions, the comparative advantage sought by industries that need carbon offsetting is eliminated.

\footnotetext{
90 BULLOCK et al., A Dangerous..., cit., at 19. In words of GILBERTSON and REYES, "the CDM obstructs the vital social change that is so fundamental to the future of the planet" (id., "Carbon Trading...”, cit., at 86).

${ }^{91}$ Ibid., at 50 and 54-ff.

92 TORRES CAMPRUBI, A. \& FERNÁNDEZ EGEA, R.M., “Crónica sobre Derecho Internacional del Medio Ambiente”, Revista Electrónica de Estudios Internacionales, n. 19, 2010, at 8; see also: http://www.eenews.net/public/climatewire/2010/06/14/2 (last visited: 10/11/2011).

93 LOHMANN, “The Dyson Effect...”, cit., at 45. LOHMAN states that "buyers have focused on large blocks of low-cost, easy-to-obtain pollution licenses, being reluctant to involve themselves in projects involving long-term sustainability considerations and local sensibilities”. Ibid., at 46.

${ }^{94}$ SOLTAU, Fairness..., cit., at 131. It has been affirmed that since to prove "additionality" one has to show that no laws compelling the introduction of new technology, there is a great pressure from companies so that developing countries do not implement such laws. Ibid.
} 
By the same token, emerging countries that would most probably have to assume commitments in the future climate regime would then see that the cheapest ways to reduce emissions have already been coped with CDM projects, as industrialized countries have already chosen all the projects that produce the greatest reduction at a lower price. Therefore, it will be expensive for developing countries to meet their future domestic emissions reduction. ${ }^{95}$ Consequently, offsetting exacerbates inequality because it allows industrialized countries to circumvent their reductions commitments, while developing countries have no option but to reduce emissions since they are selling their quotas to the industrialized countries.

CDM projects can also bring social and environmental problems to the regions where they are fulfilled. There is some evidence that they could lead to social conflicts or repression of local communities, as well as to the use of enormous quantities of environmental goods such as land or water. ${ }^{96}$ This is not surprising, since the purpose of the carbon market is to focus on providing short-term abstract emissions targets with minimal costs instead of investing in long-term projects that will lead to a fossil-free economy or to pay attention to the community needs or local environmental impacts. ${ }^{97}$ Some authors denounce the transfer of western structures and values into developing countries, creating a sort of “carbon colonialism”. 98

\subsection{The (un)sustainable development in host countries}

It is also worth examining if the investment carried out by CDM projects leads to sustainable development or they are just creating needs that were previously inexistent in those places; needs that favor investors and their origin countries above all. ${ }^{99}$

The projects are chosen not because of their environmental effectiveness or their benefits to the host population, but on a cost-effectiveness basis. ${ }^{100}$ Investors seek cheap

\footnotetext{
${ }^{95}$ BROWN, “Ethical Issues...”, cit.; OTT \& SACH, Ethical Aspects..., cit., at 21.

${ }^{96}$ And they usually "take place in regions where people have little political power" (GILBERTSON \& REYES, “Carbon Trading...”, cit., at 58).

${ }^{97}$ Ibid., at 58 .

${ }^{98}$ VAN ASSELT \& GUPTA, “Stretching too far...”, cit., at 337.

${ }^{99}$ In 2007 only 1,6\% of CERs came from projects with sustainable development benefits (BULLOCK et al., A Dangerous..., cit., at 22).
} 
ways to reduce GHG emissions. ${ }^{101}$ The CDM projects, although authorized by local authorities, are chosen by companies of developed countries according to their reduction needs, but not necessarily to the interests of the people living in the host country. ${ }^{102}$

Merely reducing emissions, however, is not enough to generate sustainable development. It has been said that investing in renewable energy is a way of promoting sustainable development. ${ }^{103}$ High-carbon investments, such as the transfer of clean technology or the investment in "decarbonising” the host-countries' economies, are preferred because they are more cost-effective.

Developing countries are also concerned that industrialized countries tend to convert development projects and development aid into CDM projects, arguing that they should also bring development and quality of life to developing countries. Climate funds should be new and additional to development aid, since they are considered by developing countries as payments for the historical responsibility of past emissions. ${ }^{104}$ Industrialized countries should carry out direct transfers of economic and technological resources to mitigate climate change instead of carbon offsets.

As a matter of fact, according to the UNFCCC, industrialized countries should assist developing countries with their financial and technological support in order to tackle climate change. If this technological transfer is not accomplished, poor nations will be forced to increase their GHG emissions to satisfy the basic needs of their population. ${ }^{105}$ Only sufficient resources can guarantee the participation of developing countries on equal footing in the functioning of the flexible mechanisms in the future climate change regime. ${ }^{106}$

\footnotetext{
${ }^{100}$ Many authors refer to CDM projects dealing with the abatement of hydro fluorocarbons (HFCs) and nitrous oxide (N2O), which provides large numbers of CERs with little costs and without introducing new technology (BULLOCK, A Dangerous..., cit., at 20; TREIBER, “Clean Development...”, cit., at 44-ff).

${ }^{101}$ This has been referred to as the "low-hanging fruit" effect. VAN ASSELT \& GUPTA, "Stretching too far...”, cit., at 349.

${ }^{102}$ As TRIBERS concludes, "the actual effect of the CDM is that it operates primarily as a financial market, not a development fund or a sustainability-promoting programme" (id. "Clean Development...", cit., at. 57).

${ }^{103}$ Ibid.

${ }^{104}$ DUBASH, “Copenhagen...”, cit., at 10.

${ }^{105}$ BROWN et al., White Paper..., cit., at 19.

106 VAN ASSELT \& GUPTA, "Stretching too far...", cit., at 343. These authors also observe that "[d]eveloping countries could be further at a disadvantage, because they lack the infrastructure and managerial capabilities necessary to evaluate and negotiate potential bargains”. Ibid.
} 
Furthermore, the replacement of aid funds with CDM projects can be problematic to certain sectors such as health or education, where no CDM projects are being accomplished. It can also be discriminatory for countries that do not host CDM projects because their GHG emissions are too low. ${ }^{107}$ Most projects concern investments in the highest polluting industries in the South (China, India, etc.), and not exactly on countries that would need an inversion in development and transfer of clean technology (such as African countries). ${ }^{108}$ It is difficult to envisage if this pattern would change in the case that emerging countries assume some reduction commitments.

In order to solve this situation, some authors suggest the creation of a bank under the control of developing countries, so they are not subject to profit-taking market power by CDM credit buyers. ${ }^{109}$ In any case, their participation in the CDM has to meet their development needs, and should not compromise their long-term interests. ${ }^{110}$ It has been sustained that it would be the case if the CDM strictly focuses on assisting non-Annex Icountries in the transition to a non-carbon economy. ${ }^{111}$

\section{COMMON AND GENERAL CRITICS TO THE MARKET-BASED MECHANISMS FROM AN ENVIRONMENTAL AND EQUITY POINT OF VIEW}

\section{Distraction from the main goal}

Although it is still too soon to verify the effectiveness of the Kyoto mechanisms, especially when dealing with the long-term CDM projects, emissions have not decreased at the desirable level. In fact, it has been said that these mechanisms "mask

\footnotetext{
${ }^{107}$ The same can be sustained for small, community-scale projects which are not usually wanted because they not compensate the transaction costs (SOLTAU, Fairness..., cit., at 204).

108 Only ten countries (India, Brazil, Indonesia, China, Korea, Vietnam, Costa Rica, Chile, Peru and Thailand) accumulate $80 \%$ of the CDM projects, whereas very few African countries are host of those projects. China and India will most probably concentrate $75 \%$ of the projects (KEULARTZ, "Kyoto...", cit., at 145). It is expected that Asia and Latin America will generate around 95\% of CERs through 2012, while Africa will get only 3\% (SOLTAU, Fairness..., cit., at 82).

It is also true that most African countries lack the adequate legal and technical means to incentive or make possible the undertaking of the CDM projects, referred as an "institutional bottleneck" (VAN ASSELT \& GUPTA, "Stretching too far...”, cit., at 353).

${ }^{109}$ Ibid.

${ }^{110}$ CAZORLA \& TOMAN, “International Equity...”, cit., at 16.

${ }^{111}$ OTT \& SACH, Ethical Aspects..., cit., at 21.
} 
the failure of actual reductions in greenhouse gas emissions”112: they are seen as a way of paying for absolution rather than changing their behavior and as an excuse for business as usual with regards to pollution.

The economic instruments are doing very little to meet the climate change regime main goal, which is to reduce emissions due to fossil energy sources (which is the major contributor to human induced climate change). Likewise, the possibility to buy emissions credits or allowances produces a delay of decreasing emissions at the source as well as of the investment on new clean technology. Instead of setting a deadline to use fossil fuels, emissions create a new tradable commodity. ${ }^{113}$ The mere fact of creating a new commodity and a new market focuses the attention of States and industries on seeking profit rather than on mitigating climate change. ${ }^{114}$

As it has been already mentioned, the transfer of clean technology and financial assistance is not necessarily cost-effective, but they are essential for sharing the burden of environmental protection on a fair basis. Yet, the focus on the functioning of the flexible mechanism shifts the attention away from this goal. ${ }^{115}$ In fact, it has been criticized that CDM projects develop existing technologies, rather than stimulating shifts to a more sustainable future. ${ }^{116}$

Furthermore, they can become a way of shifting responsibilities from emitting States to others, usually from rich countries to emerging or poor ones. ${ }^{117}$ There is no elimination

\footnotetext{
112 People's Agreement, World People's Conference on Climate Change and the Rights of Mother Earth, April $22^{\text {nd }} 2010$, Cochabamba, Bolivia.

${ }^{113}$ GILBERTSON \& REYES, “Carbon Trading...”, cit., at 17.

${ }^{114}$ Ibid., at 3.
}

In words of VAN ASSELT and GUPTA: “This commodification of the atmosphere could contribute to the diffusion of Western notion of cost effectiveness, free markets, law and economics, and property rights, even when it is unclear whether such notions favour, and are favoured by developing countries, or are compatible with environmental protection” (VAN ASSELT \& GUPTA, "Stretching too far...”, cit., at 338).

${ }^{115}$ VAN ASSELT \& GUPTA, “Stretching too far...”, cit., at 340.

${ }^{116}$ See some case studies in this sense in GILBERTSON \& REYES, “Carbon Trading...”, cit., at $66 \mathrm{ff}$.

The successful reduction of sulfur dioxide $\left(\mathrm{SO}_{2}\right)$ emissions due to a trade scheme in the US served as a big motivation to introduce a trading system into the international climate change regime. Established by the US Clean Air Act of 1990, it was responsible for the reduction of $40 \% \mathrm{SO}_{2}$ emissions by coal-burning power plants during the period of 1990-2004 with fewer costs as anticipated. Although it "did not foster technological innovations of the type that would be relevant to the climate crisis" (LOHMANN, "When Markets...”, cit., at 34).

${ }^{117}$ GILBERTSON \& REYES, “Carbon Trading...”, cit., at 31. 
of emissions at the source, but somewhere else, where it is cheaper to do so. It is widely agreed that this is possible because climate change is created irrespectively of the origin of emissions, although this assertion does not acknowledge the fact that reducing or emitting GHGs could have other effects on the given environment and population where such activities are taking place.

Shifting responsibilities has also as perverse effect that if it is not accomplished by a serious reduction policy within the industrialized countries, companies and people will keep doing business as usual since they are not aware of the problem. Domestic action will be delayed because they rely on those projects abroad. As a matter of fact, the existence of carbon offsetting and the trading schemes find its justification in the willingness of continuing the northern production and consumption patterns, energy use included. ${ }^{118}$

Also, no attention is paid to which type of industries are making the given reduction and if those industries benefiting from these flexible mechanisms are to be supported regarding the effects on the environment and social justice of their activities. Emissions reductions are treated as equal, regardless of the effects on the society and environment. $^{119}$

Therefore, these flexible mechanisms do not comply with one of the requisites to benefit from them: their supplementary character. This requires countries to meet their commitments mainly through domestic reductions, and to use these mechanisms only on a supplementary basis. According to this requirement, Annex I countries could be suspended from using those mechanisms if they cannot prove that their national activities are the principal means to comply with their reductions obligations. ${ }^{120}$ The

As it has been sustained, "the world needs development countries to cut their own emissions first and fast and pay up for adaptation and mitigation in developing countries” (BULLOCK et al., A Dangerous..., cit., at 2).

${ }^{118}$ Ibid.

${ }^{119}$ LOHMANN stresses the fact that many of these industries are benefiting from cheap opportunities for emission reductions even if in the short and long term it will not lead them to a structural change away from fossil fuels (id., "When Markets...”, cit., at 33-34).

120 Article 17 Kyoto Protocol establishes that emission trading should be supplemental to domestic actions. Although "supplementary" is not defined, and a concrete limit to use the flexible mechanisms has not been settled, according to Decision 15/CP.7 "the use of the mechanisms shall be supplemental to domestic action and that domestic action shall thus constitute a significant element of the effort made by each Party included in Annex I to meet its quantified emission limitation and reduction commitments under Article 3, paragraph 1" (Marrakech accords, 29 October-10 November 2001, available at: http://unfccc.int/resource/docs/cop7/13a02.pdf: last visited: 10/11/2011). 
observance of the supplementary principle is important not to undermine the leadership of industrialized countries in undertaking the major responsibility to mitigate climate change.

\section{Privatization of Nature and global commons}

Another problem is the privatization of Nature or as BROWN puts it: "the allocation of global commons resources for private consumption”. ${ }^{121}$ As the Seabed or the celestial bodies, the atmosphere can be considered Common Heritage of Mankind. It means that no State can exercise sovereignty over it. However, since all can profit from it and its protection, even if they do not participate in mitigating climate change (free rider phenomenon), some argue that it is necessary to "privatize" the use of the atmosphere in order to prevent its misuse as well as to distribute responsibilities. ${ }^{122}$

Nevertheless, since global commons do not have owners or they are "owned” by all, it is difficult to justify that one private person or entity could acquire a property right that excludes others from the use of that resource. ${ }^{123}$ On the contrary, everyone has the duty to protect global commons, which also means to prevent their private appropriation or use. $^{124}$

Yet, it has been said that it is not the atmosphere what is being object of trade but the emissions rights, whose value can be certified (in contract to environmental goods that are not easily valuable). ${ }^{125}$ Therefore, the question is not how much does it cost to have a clean atmosphere, but what is the cost of each pollution unit for a company/enterprise to function.

One solution to solve this crash is to allow private entities to use these commons goods during a limited period of time. Entitlements to emit GHG should not be forever and cannot be subject to appropriation. Allowances would be only a "temporary property

\footnotetext{
${ }^{121}$ BROWN, “Ethical Issues...”, cit.

122 This has been widely discussed by economists and ecologists for decades, especially after the publication of the "Tragedy of commons" by Garrett Hardin, although its postulates have been often challenged, lately by the 2009 Nobel prize-winner Elinor Ostrom, supporting the idea that common goods can be very well protected by local communities instead of being privatized.

${ }^{123}$ BROWN, “Ethical Issues...”, cit.

${ }^{124}$ As RAJAMANI notes, "since the atmosphere is a common heritage of humankind, equity has to be the fundamental basis for its management” (id., Differential Treatment..., cit., at 233).

${ }^{125}$ SANZ RUBIALES, El Mercado..., cit., at 48.
} 
right” subject to specific conditions and reservations (like a rent), but not a "permanent right to emit at the level prescribed by the allowance”. ${ }^{126}$ These rights could also be rescinded if the existing cap is not sufficiently protective of human health or the environment. Still, one could argue that granting a right to emit will pose a limit to further governmental or international actions with the aim of reducing GHG emissions, since the right holder could ask for damages if he could not properly enjoy his right.

The time limitation of the emissions permits would also prevent speculation and the possibility of some agents to acquire allowances to be re-sold in the future if scarcity of allowance makes the prices go up. Some companies could buy offsets for precompliance in the fear of price increment due to the possible settlement of a mandatory cap and trade regime within their countries. This would also exclude the possibility of carrying emissions allowances from one compliance period to the following, what is known as "banking”.

The price of the emission permits should not be considered, therefore, as a rent of property but as a fee for using Nature temporally as a sink beyond its capacity. As some authors have rightly considered: "[m]oney gives the right to access, but not to ownership”. ${ }^{127}$ It is then important to highlight that trading with permits should not be identified with the most efficient way to allocate reductions abatement, but with forming the price of the overuse of Nature. Accordingly, revenues of those permits should belong to all citizens due to the global common nature of the atmosphere. ${ }^{128}$

\section{Adequacy of the "free market" approach: dichotomy between command and control measures and economic incentives}

The use of "economic" or "market-based" mechanisms is based on the idea that environmental harm has been traditionally seen by economists as an externality or market failure that justified the action of the State. As governmental action is not always cost-efficient, the solution is to "internalize" those environmental costs in the market again. ${ }^{129}$ A way of internalizing these costs is the "polluter pays" principle, which

\footnotetext{
${ }^{126}$ BROWN, “Ethical Issues...”, cit.

${ }^{127}$ OTT \& SACH, Ethical Aspects..., cit., at 14.

${ }^{128}$ Although, according to art. 12.9 of the Kyoto Protocol, 2\% share of the proceeds from CDM projects are destined to the Adaptation Fund.

${ }^{129}$ SANZ RUBIALES, El Mercado..., cit., at 36-38; KRUGMAN, “Building...”, cit.
} 
implies that those who generate negative externalities to the environment because of their economic activities should pay for it.

These externalities can also be dealt with regulations establishing prohibitions or limitations (command and control measures). Yet market measures are considered to provide greater environmental effectiveness as command and control measures because they turn GHG reductions into marketable assets and, thereby, create tangible financial rewards for environmental performance. Command and control measures are criticized for being excessively rigid, insensitive to geographical and technological differences, and for being inefficient.

Therefore, it is maintained that it is more effective to formulate economic incentives to the private sector to foster the voluntary elimination of the negative effects on the environment. ${ }^{130}$ Theoretically, they also prompt technological and process innovations that reduce emissions down to or beyond required levels. In addition, it has been argued that market mechanisms bring a fair allocation of costs because their efficiency results in greater overall welfare. ${ }^{131}$ Many point out the practical example of the US acid rain program to affirm that market mechanisms are useful tools to reach environmental goals along economic well-being. ${ }^{132}$

Some scholars, even environmentally sensible, think that the implementation of the flexible mechanisms is better than doing nothing, and that it is the only way to hook companies and other agents to mitigate climate change. ${ }^{133}$ Nevertheless, for many environmentalists it is an environmental crime that cannot be subjected to incentives. In their opinion, dealing with the problem of climate change through market or economic mechanisms where only the cost-effectiveness element and its numbers are taken into

\footnotetext{
${ }^{130}$ It has been argued that "direct regulation of activities that cause pollution makes sense in some cases" but "it is seriously defective in others, because it does not offer any scope for flexibility and creativity" ( KRUGMAN, "Building...", cit.). In fact, at the EU level it has been sustained that traditional regulatory policy instruments to mitigate GHG emissions had failed in the 1990s (VAN ASSELT, "Emission trading...”, cit., at 131).

${ }^{131}$ CAZORLA \& TOMAN, “International Equity...”, cit., at 8.

132 Environmental Defense Fund (EDF), The power of markets to help the planet, available in: http://www.edf.org/page.cfm?tagID=1085 (last visited: 10/11/2011). Although it has been affirmed that the success of this program was due to other contextual circumstances and factors. GILBERTSON \& REYES, “Carbon Trading...”, cit., at 20; VAN ASSELT, “Emission trading...”, cit., at 126.

${ }^{133}$ LOHMANN criticize that "Although they form part of a 35-year-old pattern of neoliberalism and financialisation that is now being called into deep question, carbon markets remain the dominant official response to climate change worldwide.” (LOHMANN, "When Markets...”, cit., at 2).
} 
account, is a way of depoliticizing climate action. ${ }^{134}$ In fact, SOLTAU rightly underlines that climate change cannot be mitigated alone by taking into account the cost-effectiveness of actions, since those type of assumptions are not only based on economic numbers or scientific evidence, but also on ethical and moral values. ${ }^{135}$ The flexible mechanisms can succeed in achieving emissions reductions at the lower costs, but they fail in contributing to other auxiliary -but important- goals such as sustainable development and technology transfer to developing countries. ${ }^{136}$

Cap and trade, considered by some as a mechanism based on market functioning and not adequate to deal with environmental problems, is at the same time criticized because it implies some kind of State intervention, considering it as a command and control mechanism. In fact, the cap and trade mechanism is a mixture of command and control (setting the cap) and economic (allowing trade) measures. ${ }^{137}$ Certainly, there is a governmental intervention while setting the cap, but also by setting the punishment in the case that companies fail to reduce their emissions down to the mandatory limit. So, cap and trade schemes are under State control and they do not substitute governmental regulations; they are simply a complement of it. ${ }^{138}$

Furthermore, the functioning of the market requires a very robust administrative control system in order to be effective. ${ }^{139}$ The possibility of selling the emissions allowances of one company to another that emits more than permitted does not differ from the fact that both would have exhausted their allowances (regarding environmental effects); it only introduces a way of "flexibilizing" their activities and making them comply with the limit more efficiently. ${ }^{140}$

However, as said before, there are great doubts to rely the solution of environmental problems to markets. ${ }^{141}$ Cap and trade schemes have a high market dependency. Carbon prices are volatile and as a commodity, they depend on market fluctuations. A high

\footnotetext{
${ }^{134}$ Ibid., at 32.

${ }^{135}$ SOLTAU, Fairness..., cit., at 14.

${ }^{136}$ VAN ASSELT \& GUPTA, “Stretching too far...”, cit., at 377.

${ }^{137}$ SANZ RUBIALES, El Mercado..., cit., at 39.

${ }^{138}$ Ibid., at 87.

139 The governmental power has to follow, verify and register all emissions. Ibid., at 89.

${ }^{140}$ Ibid., at 88.

${ }^{141}$ See generally, LOHMANN, “When Markets...”, cit.
} 
price would make the dirty industry too expensive, and powerful lobbies are already taking measures to avoid this . Besides, those mechanisms seem to legitimize the idea that the environment and its resources may be the subject of purchase and sale. Economic mechanisms presuppose that emissions can be prized and measured accurately, which is not all that clear.

It is also highly questionable whether they can bring ecological benefits, since they reflect the economic model that has led us to this environmental crisis. In fact, the carbon market is beginning to adopt the same tradable commodities (future trading and derivatives) as the financial markets that have led us to the current economic crisis. That is no wonder since the carbon market has been conceived by the same people. ${ }^{142}$

The search of economic efficiency leads most of the time to environmental ineffectiveness and, therefore, to social injustice. The idea of obtaining as many emissions reductions as possible with as little money as possible, borrows the logic that rules the actual wave of economic globalization into the environmental area. ${ }^{143}$ As SOLTAU notes, "it is not certain that a stringent global climate change target is, in practice, compatible with economic growth of the kind to which the world has become accustomed”. 144

Some authors maintain that the philosophy "more is better" is clearly unsustainable nowadays. ${ }^{145}$ That is because "[m]arkets are growth-oriented, so new sources of accumulation are imperative for market survival” and this opposes the fight against climate change that should deal with "reducing the causes of climate change, rather than building up a tradable commodity". ${ }^{146}$ The objective of the transition to a low emission

\footnotetext{
${ }^{142}$ CARBON TRADE WATCH, "Carbon Trading...", cit. In the words of LOHMANN "some of the same bricoleurs and theorists have helped create both the financial derivatives markets and the carbon markets" (id. "When Markets...", cit., at 26).

${ }^{143}$ OTT \& SACH, Ethical Aspects..., cit., at 16.

${ }^{144}$ SOLTAU, Fairness..., cit., at 12-3.

145 ESTÉVEZ ARAUJO, J.A., “¿Es necesario un cambio cultural profundo para superar la crisis ecológica?”, Mientras Tanto, n. 79, 2010.

${ }^{146}$ CARBON TRADE WATCH, "Carbon Trading...”, cit. Also, according to the People's Agreement, World People's Conference on Climate Change and the Rights of Mother Earth, April $22^{\text {nd }} 2010$, Cochabamba, Bolivia:

"The capitalist system has imposed on us a logic of competition, progress and limitless growth. This regime of production and consumption seeks profit without limits, separating human beings from nature and imposing a logic of domination upon nature, transforming everything into commodities: water, earth, the human genome, ancestral cultures, biodiversity, justice, ethics, the rights of peoples, and life itself.”
} 
economy necessarily implies the change of western life patterns (production, transportation, consumption, etc.). Therefore, in the words of OTT and SACH, "it is not enough that the polluter pays; the polluter has got to change as well”. ${ }^{147}$

\section{CONCLUSIONS}

From a political and economic point of view, it is almost undeniable that the flexible mechanisms remain in the future climate regime. Yet we have already observed that the flexible mechanisms face many problems concerning equity and environmental effectiveness. Therefore, it is crucial to point out some changes that will need to be undertaken regarding their future configuration and implementation. ${ }^{148}$

Within the modifications to be made, and in order not to disregard their environmental goal, it is vital that they remain as a supplementary mean to the goal of reducing GHG which has to take place by the elimination of free allowances within the trading system and the limitation of offsetting. Efforts should not result in withering offsets possibilities that can distract the attention from the main obligation, which is to reduce GHG emissions domestically. Flexible mechanisms should not lead to legitimizing "business as usual" (either in developed or in developing countries) and financial, technological and creativity efforts should be destined to finding real ways of reducing GHG emissions. Also, in order to take into account equity concerns, the project based mechanisms should be different and additional to development aid, revenues from global commons overuse should not be privatized, and their focus should be on the transfer of clean technology and financial means.

Furthermore, the only way to provide sustainable development is to balance the economic efficiency element with the criteria of environmental effectiveness and equity- that have often been absent in the international negotiations on climate change.

\footnotetext{
"We similarly denounce the way in which the capitalist model imposes mega-infrastructure projects and invades territories with extractive projects, water privatization, and militarized territories, expelling indigenous peoples from their lands, inhibiting food sovereignty and deepening socio-environmental crisis."

${ }^{146}$ OTT \& SACH, Ethical Aspects..., cit., at 17.

${ }^{147}$ Ibid.

${ }^{148}$ Some other useful suggestions to undertake on the flexible mechanisms to turn them into more equitable systems that also pay attention to environmental integrity in VAN ASSELT \& GUPTA, "Stretching too far...", cit., at $356 \mathrm{ff}$.
} 
Therefore, in the short-middle term, a radical change in our technological and productive system has to be accomplished. An adjustment of the energy system will not be sufficient, but a transition from actual fossil fuels based economies to a new and alternative model based on low-carbon consumption, transport and production activities. $^{149}$ This shift will not only bring environmental integrity but it will also address intra-generation and inter-generation equity concerns, as well as preventing serious economic costs for not undertaking such changes now.

\section{BIBLIOGRAPHY}

- BOYLE, A. and FREESTONE, D., International Law and Sustainable Development: Past Achievements and Future Challenges, Oxford University Press, 1999.

- BROWN WEISS, E., “Climate Change, Intergenerational Equity and International Law”, 9 Vermont Journal of Environmental Law, 2008, 615-627.

- BROWN, D.A. et al., White Paper on the Ethical Dimensions of Climate Change, The Collaborative Program on the Ethical Dimensions of Climate Change, Rock Ethics Institute, Penn State University, 2006; available at: http://rockethics.psu.edu/climate/whitepaper/whitepaper-intro.shtml (last visited: 10/11/2011).

- BROWN, D.A., “Ethical Issues Raised by Carbon Trading”, 15 June 2010; available at: http://rockblogs.psu.edu/climate/2010/06/ethical-issues-raised-bycarbon-cap-andtrade-regimes.html\#more (last visited 10/11/2011).

- BROWN, D.A., Minimum Ethical Criteria For All Post-Kyoto Regime Proposals: What Does Ethics Require of A Copenhagen Outcome, ClimateEthics.org, 2008; available at: http://climateethics.org/?p=50 (last visited: 10/11/2011).

- BUlLOCK, S., CHILDS, M., \& PICKEN, T., A Dangerous Distraction. Why Offsetting is Failing the Climate and People: The Evidence, Friends of the Earth, June 2009; available

at:

\footnotetext{
149 The achievement of a "green economy" is one of the main themes of the forthcoming UN Environmental Conference that will take place in 2012 in Río de Janeiro (Rio +20 ); see UN Doc.A/RES/64/236, 31 March 2010; available at: $\underline{\text { http://ods-dds- }}$ ny.un.org/doc/UNDOC/GEN/N09/475/99/PDF/N0947599.pdf?OpenElement; last visited: 10/11/2011).
} 
http://www.foe.co.uk/resource/briefing_notes/dangerous_distraction.pdf

(last visited: 10/11/2011), at 8-9.

- CARBON TRADE WATCH, “Carbon Offsets”, December 2009; available at: www.carbontradewatch.org (last visited: 10/11/2011).

- CARBON TRADE WATCH, "Carbon Trading - How it Works and Why it Fails" (Chapter 4), (2009a) Critical Currents no. 7, November 2009; available at: http://www.dhf.uu.se/pdffiler/cc7/cc7_web_art4.pdf (last visited: 10/11/2011).

- CAZORLA, M. \& TOMAN, M., "International Equity and Climate Change Policy” 27 Climate Issue Brief, 2000, at 6; available at: http://blog.arts.uwa.edu.au/pols2206/files/2011/03/equityandclimatechange2ooo1.p df (last visited: 10/11/2011).

- CLAUSSEN, E. \& MCNEILLY, L., "Equity \& Global Climate Change. The Complex Elements of Global Fairness”, Pew Centre on Global Climate Change, October $29^{\text {th }} 1998$.

- DUBASH, N., “Copenhagen: Climate of Mistrust”, 52 Economic \& Political Weekly, vol. XLV, 2009.

- ENVIRONMENTAL DEFENSE FUND (EDF), The power of markets to help the planet, available in: http://www.edf.org/page.cfm?tagID=1085 (last visited: 10/11/2011).

- ESTÉVEZ ARAUJO, J.A., “¿Es necesario un cambio cultural profundo para superar la crisis ecológica?”, Mientras Tanto, n. 79, 2010, available at: http://www.mientrastanto.org/boletin-79/notas/es-necesario-un-cambio-culturalprofundo-para-superar-la-crisis-ecologica (last visited: 10/11/2011).

- FERNÁNDEZ EGEA, R.M. \& SINDICO, F., “Cambio climático y comercio: su dimensión norte-sur”, Revista de la Facultad de Derecho de la Universidad de Granada, vol. 12, 2008, 223-260.

- GILBERTSON, T. \& REYES, O., "Carbon Trading. How it works and why it fails”, 7 Critical Currents, Dag Hammarksjöld Foundation, Uppsala, 2009.

- GrubB, M., "International Emissions Trading under the Kyoto Protocol: Core Issues in Implementation”, RECIEL vol. 7, n. 2, 1998, 140-146. 
- HAHN, R.W. \& STAVINS, R.N., What Has the Kyoto Protocol Wrought? The Real Architecture of International Tradable Permit Market, The AEI Press Publisher for the American Enterprise Institute, 1999.

- KEULARTZ, J., "Kyoto and the Ethics of Flexibility", in Vermeersch; E. (ed.), Reading the Kyoto Protocol. Ethical Aspects of the Convention on Climate Change, Eburon Academic Publishers, 2005.

- KRUGMAN, P., "Building a Green Economy”, NY Times, April 5 th $^{\text {th }}$ 2010; available at: http://www.nytimes.com/2010/04/11/magazine/11Economy-t.html (last visited: 10/11/2011).

- LOHMANN, L., "The Dyson Effect. Carbon "Offset” Forestry and the Privatization of the Atmosphere”, 15 The Corner House Briefing 2009; available at: http://www.thecornerhouse.org.uk/resource/dyson-effect-0 (last visited: 10/11/2011).

- LOHMANN, L., "When Markets are Poison. Learning about Climate Policy from the Financial Crisis”, 40 The Corner House Briefing, September, 2009.

- MELÉNDEZ-ORTIZ, R. et al., “Anticipating Pressing Issues in Integration: The Trade, Climate and Sustainable Developing Nexus”, 14 Institute for the Integration of Latin America and the Caribbean, n. 30, 2010, 21-32.

- MEYER, A. \& HILDYARD, N., "Climate and Equity after Kyoto”, 03 The Corner House Briefing, published December 1997; available at: http://www.thecornerhouse.org.uk/resource/climate-and-equity-after-kyoto (last visited: 10/11/2011).

- OTT, H., \& SACHS, W., Ethical Aspects of Emissions Trading, Wuppertal Institute, 2000; available at: http://www.wupperinst.org/uploads/tx_wibeitrag/WP110.pdf (last visited: 10/11/2011).

- PAREJO NAVAS, T., "Mecanismos de lucha contra el cambio climático en un mercado europeo sostenible”, 20 Revista General de Derecho Europeo, 2010.

- RAJAMANI, L., “Neither Fish nor Fowl”, Seminar 606, February, 2010, at 29; available at: http://www.india-seminar.com/2010/606/606_lavanya_rajamani.htm (last visited: 10/11/2011). 
- RAJAMANI, L., Differential Treatment in International Environmental Law, Oxford University Press, 2006.

- SANZ RUBIALES, I. (Dir.), El Mercado de derechos a contaminar. Régimen jurídico-público del mercado comunitario de derechos de emisión en España, Lex Nova, Valladolid, 2007.

- SHUE, H., "Subsistence Emissions and Luxury Emissions”, Law and Policy, vol. $15,1993$.

- SOltaU, F., Fairness in International Climate Change Law and Policy, University Press, Cambridge, 2009.

- STERN, N., Stern Review on the Economics of Climate Change, UK Treasury, 2006; available at: http://apo.org.au/?q=node/4420 (last visited: 10/11/2011).

- TORRES CAMPRUBI, A. \& FERNÁNDEZ EGEA, R.M., “Crónica sobre Derecho Internacional del Medio Ambiente", Revista Electrónica de Estudios Internacionales, n. 19, 2010; available in: www.reei.org (last visited: 10/11/2011).

- TREIBER, M., “Clean Development Mechanism: A Symbolic Action?” UMB Student Journal of International Environment and Development Studies, vol. 1, 2011; available at: http://www.umb.no/noragric/artikkel/umb-student-journal-ofinternational-environment-and-development-studies-launched (last visited: $10 / 11 / 2011)$

- VAN ASSELT, H. \& GUPTA, J., "Stretching too far: developing countries and the role of flexibility mechanisms beyond Kyoto” 28 (2) Stanford Environmental Law Journal, 2009, 311-ff.

- VAN ASSELT, H., "Emissions trading: the enthusiastic adoption of an alien instrument?”, in Jordan, A. et al. (eds.) Climate Change Policy in the European Union: Confronting the Dilemmas of Mitigation and Adaptation?, 2010.

- VANDERHEIDEN, S., Atmospheric Justice: A Political Theory of Climate Change, 2008.

- VIÑUALES, J., "Balancing Effectiveness and Fairness in the Redesign of the Climate Change Regime”, Leiden Journal of International Law, vol. 24, 2011, 223252. 
- WERKSMANN, J., "The Clean Development Mechanism: Unwrapping the 'Kyoto Surprise””, RECIEL, vol. 7, n. 2, 1998, 147-158.

- YABAR STERLING, A., "Los mecanismos de flexibilidad de Kioto, otros instrumentos de lucha contra el cambio climático y su aplicación en la Unión Europea”, Observatorio Medioambiental, n. 4, 2001, 307-338.

- YAMIN, F. Y DEPLEDGE, J., The International Climate Change Regime. A guide to Rules, Institutions and Procedures, Cambridge, University Press, Cambridge, 2004. 